Orissa Journal of Commerce

Vol. 42, Issue 2, April-June 2021

ISSN: 0974-8482

(C) OJC India. All Right Reserved

URL: www.ojcoca.org

DOI: https://doi.org/10.54063/ojc.2021.v42i02.07

\title{
Issues and Challenges of Employing Internally Migrated Labourers: An Empirical Study with Reference to Guwahati
}

\author{
Dipankar Malakar ${ }^{1 *}$ and Shazeed Ahmed ${ }^{2}$ \\ ${ }^{1}$ Assistant Professor, Department of Commerce, Krishna Kanta Handiqui State Open University, Guwahati, Assam. \\ E-mail: dpmalakar1984@gmail.com \\ ${ }^{2}$ Assistant Professor, Assam Institute of Management, Affiliated to Assam Science and Technology University, Guwahati, Assam. \\ E-mail: shazeedahmd@gmail.com \\ ${ }^{*}$ Corresponding Author
}

To cite this paper

Malakar, D., \& Ahmed, S. (2021)

Issues and Challenges of

Employing Internally Migrated

Labourers: An Empirical Study

with Reference to Guwahati.

Orissa Journal of Commerce. 42(2), 82-94

Keywords

Migrant, Labourer, Perception, Communality, Construction, Indigenous.

JEL Classification

$\mathrm{J} 4, \mathrm{~J} 6, \mathrm{~J} 62, \mathrm{~J} 82$

\section{Introduction}

Migration is a worldwide phenomenon. It is a situation where a worker moves from one place to another in search of work or for better living conditions (Oxford Dictionary). According to International Organization for Migration, structured and properly managed labour migration has vast possibilities for governments, communities, employers, migrants and other stakeholders in the countries of origin and destination. With newer job avenues at home, gradually countries are viewing international labour migration as a basic element for national policy and development for increasing employment. This is possible with the opportunities for employment globally and consequent inflow of foreign exchange. Migration thus leads to growth of economy and innovations in the place of destination. It further emancipates the burden of poverty in the place of origin. However there are issues like abuses committed on migrants by recruiters and the separation of migrants from families, leading to stress and immigration 
at a higher level. This in turn can create grave challenges to the identity and sovereignty of a nation. Hence both favourable and adverse effects are associated with the event of migration (Weiner, 1995).

According to World Migration Report (2010), the number of migrants globally would double from 214 million in 2010 to 405 million by 2050 because of reasons like variations in demography, environmental changes, revolutions in technology and social networking. Migrants often have the tendency to reflect on the opportunities of the labour market available, both in the rural and urban areas and the scope of landing on an urban job (Todaro, 1969). Of late the rate of migration from the rural to the urban areas has been quite significant as more people moved from the rural areas to the urban centres (Gimba and Kumshe, 2001). At the same time the rate of population growth has risen with the phenomenon of internal and international migration (Srivastava, 1968). Thus rural to urban movement leads to pressure on the urban housing and environment (Gimba and Kumshe, 2001) as well. According to Economywatch (2010), the construction sector is a thriving industry and with rapid development, the movement of people from rural to the urban areas often takes place. With increase in emphasis on infrastructure and housing, construction sector in India has become an important component of the economy.

The phenomenon of labour movement to the valley of Assam in the north eastern part of India can be broadly classified into two major categories namely the international immigrants mostly from neighbouring Bangladesh and the internal migrants where movement is from one place to another within the state. Guwahati being the prime urban centre in Assam account for around 24 percent of the urban population of the state (Borah, 2011). According to India Population Report 2020 which takes input from UN World Urbanisation Prospects, the population of Guwahati in 2020 is estimated at 2.381056 million. With the increase of purchasing power of the people and availability of easy credit, the boom in real estate and infrastructure sector is visible. This makes infrastructure development the thrust area for Guwahati. Consequently, demand for various construction workers for providing the services of mason, carpenter, plumber, unskilled labourers and helpers have increased. To meet this growing demand, there is internal migration of workers from various rural districts within the state like Barpeta, Dhubri, Darrang, Goalpara, Kamrup (rural), Nalbari, Morigaon to Guwahati.

\section{Review of Literature}

A few notable research works has been reviewed related to migration of labourers. They have found a place among the selected few because they have made an impact in the proposed area of study.

Migration of labourers from the rural to the urban areas takes place primarily for economic reasons. It provides employment (Malhotra and Devi, 2017; Lalrampuii, 2016; Mahapatro, 2014) and leads to better standard of living (Debnath et al., 2017; Mander and Sahgal, 2010). It provides scope to the migrant to save and remit money to native places and further educate children (Mander and Sahgal, 2010). Consequently it rescues poverty stricken households in both the delivering and the receiving ends by a self help mechanism (Handral et al., 2018). Mahapatro (2013) contend that structural adjustment programmes in rural areas has led to rural urban migration and it is being increasingly used as a survival strategy by majority of the male. Lalrampuii (2016) highlighted multiple factors as instrumental in promoting migration in north east India, out of which one significant factor is population pressure.

Orissa Journal of Commerce, 42(2) (C) 2021 
Migration leads to rapid growth in the urban areas with a huge inflow of people to the city (Debnath et al., 2017). The phenomenon of urbanization and per capita credit to industry has a positive linkage with the volume of in-migration. On the other hand per capita income has a negative linkage with the size of out-migration (Malhotra and Devi, 2017). As migrants provide cheap labour for economic development (Handral et al., 2018), they are a preferred lot. They are easier to be managed under complex conditions and their supply can be simply and effortlessly augmented or reduced at a low cost to the employers. Further migrant workers can work for longer duration with flexibility (Sanyal and Maity, 2018).

However migrated labourers in the urban areas encounter several issues in terms of lack of identity, right to education, food security, shelter, health and financial inclusion (Borhade et al., 2016). Mander and Sahgal (2010) highlighted the distress of internal migrant labourers in the form of poor working conditions, habitat available, poor social protection (Jane, 2016) and fear of displacement. Further though laws exist for protection of the rights of migrant labourers, there are abuses of rights committed by the employers and intermediaries (Mahapatro, 2013). To address the issue of rural to urban migration, there is a need for a proper smart city planning for the future growth in urban areas (Debnath et al., 2017) as well as a nationwide documentation exercise of labourers moving out from rural areas (Borhade et al., 2016). There is also a need to formulate policies for the welfare of the migrant labourers and their families residing in urban areas in terms of safeguarding their rights so as to get context specific service (Jane, 2016).

The past studies looked at the problem of migration from the perspective of environmental geography, political science, history and other branches of social sciences. Further the past studies were conducted using theoretical frameworks of the respective fields and were based on qualitative analysis. However it has been felt that empirical research works on the issue of using rural to urban migrated labourers at Guwahati in the construction sector is rare. To fulfill the identified gap, a need is felt to understand the perception of citizens towards internal (rural to urban) migration of labourers and address the contentious issues involved in their employment.

\section{Objectives of the Study}

The main objectives of this study are:

- To study the perception of citizens towards employing internally migrated labourers from rural areas of the state to Guwahati in the construction sector.

- To identify the key issues and explore the key managerial implications so that such labourers can be employed optimally.

\section{Research Methodology}

\subsection{Definitional Perspective}

Internally migrated labourers are labourers who migrate from various rural areas of the states including char (river island of Brahmaputra) areas to Guwahati but do not habitually stay at Guwahati; Indigenous labourers are local labourers who habitually stay at Guwahati or at the vicinity throughout the year and provide labour services. 


\subsection{Attitudinal Statements}

The research design was exploratory by character based on collection of primary data from field survey. Initially a total of 25 attitudinal statements related to probable opinions on the issue of employing internally migrated labourers in the construction sector were developed. These statements were framed taking into account the views expressed by experts during a focus group interviews conducted with a group of 7 experts in the field, taking input from the reviewed papers and from other secondary literature. The 25 statements developed are in Table 1.

Table 1: Reliability Score of Attitudinal Statements

\begin{tabular}{|c|c|c|}
\hline & Attitudinal Statements & \\
\hline S1 & Internally migrated labourers are readily available in comparison to indigenous labourers & \\
\hline S2 & Internally migrated labourers provide stiff competition to indigenous labourers available & \\
\hline S3 & Internally migrated labourers are more innovative in comparison to indigenous labourers & \\
\hline S4 & Internally migrated labourers have easy accessibility in comparison to indigenous labourers & \\
\hline S5 & Internally migrated labourers create pollution problems in the locality than indigenous labourers & \\
\hline S6 & Internally migrated labourers are more industrious than the indigenous labourers available & \\
\hline S7 & Internally migrated labourers can perform multiple task compared to indigenous labourers & \\
\hline S8 & Internally migrated labourers create more environmental problem than indigenous labourers & \\
\hline S9 & Internally migrated labourers are a source of petty crimes in the city than indigenous labourers & $\stackrel{\infty}{\circ}$ \\
\hline S10 & Internally migrated labourers can be managed and motivated easily than indigenous labourers & $\frac{\pi}{2}$ \\
\hline S11 & Internally migrated labourers hardly contribute anything to government revenue earnings & $\underset{Z}{Z}$ \\
\hline S12 & Internally migrated labourers can do more work with limited resources than indigenous labourers & 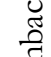 \\
\hline S13 & Internally migrated labourers have easy accessibility in comparison to indigenous labourers & : \\
\hline S14 & Internally migrated labourers create pollution problems in the locality than indigenous labourers & \\
\hline S15 & Internally migrated labourers are more industrious than the indigenous labourers available & \\
\hline S16 & Internally migrated labourers can perform multiple task compared to indigenous labourers & \\
\hline S17 & Internally migrated labourers create more environmental problem than indigenous labourers & \\
\hline S18 & Internally migrated labourers are a source of petty crimes in the city than indigenous labourers & \\
\hline S19 & Internally migrated labourers can be managed and motivated easily than indigenous labourers & \\
\hline S20 & Internally migrated labourers hardly contribute anything to government revenue earnings & \\
\hline S21 & Internally migrated labourers complain less at tasks assigned than indigenous labourers & \\
\hline S22 & Internally migrated labourers are very flexible at work in comparison to indigenous labourers & \\
\hline S23 & Internally migrated labourers can work more till late hours when there arises any contingency & \\
\hline S24 & Internally migrated labourers are highly skilled compared to indigenous labourers & \\
\hline S25 & Internally migrated labourers have a lesser level of civic sense than indigenous labourers & \\
\hline
\end{tabular}

Orissa Journal of Commerce, 42(2) (C) 2021 
Dipankar Malakar and Shazeed Ahmed

For assessment of the responses against the attitudinal statement, a 5 point itemized rating scale was used. The respondents were instructed to express their rating on the statements where the rating 5 represented the item 'highly agree', 4 represented the item 'agree', 3 represented the item 'cannot say', 2 represented the item 'least agree' and rating 1 represented the item 'do not agree'. With a view to verify the reliability of the scale, Cronbach's Alpha was run and 0.842 was the score. Therefore it was accepted to be valid as the score was greater than 0.70 (Nunnally, 1978). The statements were accordingly administered (as part of the first phase of the study) on a sample of 387 respondents. The sample size selected was deemed to be sufficient as it was more than 200 which was the minimum sample size prescribed for behavior studies and based upon affordability (Sudman, 1976).

\subsection{Sampling Plan}

Among the sampling units, 105 belonged to the public sector / government sector, 121 belonged to the private sector, 72 were self-employed, 65 were professionals, 14 belonged to the unemployed / housewife / student category and 10 were senior citizen of the city. The study used convenience sampling technique. A structured questionnaire through Google Form was used as a research instrument for data collection.

\section{Data Analysis and Interpretation}

In the first phase, Factor Analysis was applied to reduce the number of attitudinal statements to a manageable level and to optimize the content validity. The initial 25 attitudinal statements were used as factors. Principal Component Analysis was run and primarily three pivot tables with output namely Factor Matrix, Final Statistics as given in Table 2 and Rotated Factor Matrix as given in Table 3 were extracted. Table 2 reflected the 25 variables (only 10 variables shown) with their communality along with the Eigen value of all factors with a value of 1 or more than 1 . From Table 2 it was found that 9 factors had Eigen value of 1 or more than 1 and together accounted for 79.70 percent of the variance on an overall basis. Further through rotation of the components (using Varimax with Kaiser Normalization) the variables were reduced from 25 to 9 factors.

Table 2: Final Statistics

\begin{tabular}{lrrrrr}
\hline Variable & Communality & Factor & Eigen value & Pct of variable & Cum pct \\
\hline VAR00001 & .710 & 1 & 3.123 & 12.493 & 12.493 \\
VAR00002 & .828 & 2 & 2.840 & 11.360 & 23.852 \\
VAR00003 & .620 & 3 & 2.444 & 9.777 & 33.629 \\
VAR00004 & .845 & 4 & 2.312 & 9.248 & 42.877 \\
VAR00005 & .824 & 5 & 2.270 & 9.079 & 51.956 \\
VAR00006 & .784 & 6 & 1.908 & 7.632 & 59.588 \\
VAR00007 & .735 & 7 & 1.846 & 7.383 & 66.972 \\
VAR00008 & .710 & 8 & 1.723 & 6.890 & 73.862 \\
VAR00009 & .897 & 9 & 1.461 & 5.844 & 79.706 \\
VAR00010 & .830 & & & & \\
\hline
\end{tabular}

The variables as above are the factors 
Issues and Challenges of Employing Internally Migrated Labourers

Table 3: Rotated Factor Matrix

\begin{tabular}{|c|c|c|c|c|c|c|c|c|c|}
\hline & 1 & 2 & 3 & 4 & 5 & 6 & 7 & 8 & 9 \\
\hline VAR00001 & .230 & .376 & -.232 & .361 & .158 & .251 & .455 & -.060 & -.182 \\
\hline VAR00002 & .160 & .044 & -.191 & .838 & -.208 & .091 & -.087 & -.020 & .043 \\
\hline VAR00003 & -.032 & .127 & .078 & -.028 & -.118 & .739 & .118 & 143 & .038 \\
\hline VAR00004 & .121 & -.215 & -.315 & .165 & .388 & .327 & .541 & -.066 & .322 \\
\hline VAR00005 & .285 & .138 & .816 & -.110 & .137 & .076 & .047 & -.063 & .122 \\
\hline VAR00006 & .423 & -.263 & .359 & .103 & -.006 & .556 & .098 & .087 & -.265 \\
\hline VAR00007 & .067 & .119 & .176 & -.177 & -.015 & .039 & .779 & .157 & .143 \\
\hline VAR00008 & -.113 & .085 & .745 & -.088 & .048 & .038 & .167 & 240 & -193 \\
\hline VAR00009 & -.015 & .107 & .088 & -.127 & .912 & -.103 & -.031 & .022 & .132 \\
\hline VAR00010 & .025 & .523 & .317 & .517 & .348 & -.073 & .213 & -.009 & .132 \\
\hline VAR00011 & -.331 & .382 & .365 & -.022 & .197 & .253 & -.003 & .559 & .005 \\
\hline VAR00012 & -.128 & .128 & .357 & .065 & .547 & -.108 & .408 & -.165 & -.094 \\
\hline VAR00013 & .409 & -.103 & .017 & .664 & .272 & -.048 & -.027 & .326 & -.083 \\
\hline VAR00014 & .782 & -.130 & -.022 & .066 & .076 & .150 & -.219 & .315 & .250 \\
\hline VAR00015 & .849 & .042 & -.019 & .270 & -.029 & -.007 & .082 & -.029 & .067 \\
\hline VAR00016 & .876 & .074 & .166 & .051 & -.079 & .052 & 215 & -.026 & .015 \\
\hline VAR00017 & 142 & .045 & -.027 & .014 & .064 & -.011 & .165 & .084 & .914 \\
\hline VAR00018 & .192 & .090 & .576 & .396 & -.050 & .475 & -.232 & .133 & .200 \\
\hline VAR00019 & .430 & .533 & .157 & .298 & .334 & -.121 & .146 & .266 & -.065 \\
\hline VAR00020 & -.104 & .804 & .099 & -.032 & .002 & .077 & .051 & -.331 & .183 \\
\hline VAR00021 & .027 & .794 & .117 & -.071 & .068 & .060 & .016 & .316 & -.060 \\
\hline VAR00022 & .104 & .431 & -.136 & .175 & .500 & .543 & .028 & -.140 & -.007 \\
\hline VAR00023 & -.013 & .530 & .011 & .351 & .487 & .285 & .113 & -.030 & -.147 \\
\hline VAR00024 & .209 & .061 & .253 & .398 & .056 & .329 & .473 & .166 & .327 \\
\hline VAR00025 & .221 & -.040 & .082 & .131 & -.155 & .112 & .142 & .836 & .122 \\
\hline
\end{tabular}

Note: $\quad$ Extraction Method: Principal Component Analysis, Rotation converged in 13 iterations variables as above are the 25 Statements used

The 9 factors were given appropriate names. This was done with a view to keep the true meaning of each factor and at the same time keeping in mind the constituent variables with high loadings of each one of the factors that were extracted. From Table 3 (Rotated Factor Matrix), it was found that for factor 1, statement 14 (Employing internally migrated labourers are more profitable for the employer), statement 15 (Internally migrated labourers have a lesser bargaining power than indigenous labourers) and statement 16 (Internally migrated labourers are available at cheaper cost compared to indigenous labourers) have high loadings of $0.782,0.849$ and 0.876 respectively. They are related and have been 
named as 'provider of cheap labour'. For factor 2, statement 10 (Internally migrated labourers can be managed and motivated easily than indigenous labourers), statement 19 (Internally migrated labourers have low level of absentism at work than indigenous labourers), statement 20 (Internally migrated labourers complain less at tasks assigned than indigenous labourers), statement 21 (Internally migrated labourers are very flexible at work in comparison to indigenous labourers) and statement 23 (Internally migrated labourers can work more till late hours when there arises any contingency) have high loadings of $0.523,0.533,0.804,0.794$ and 0.530 respectively. They are related and have been named as 'easy to manage and flexible'.

For factor 3, statement 5 (Internally migrated labourers create cleanliness problem in the locality than indigenous labourers), statement 8 (Internally migrated labourers create more environmental problem than indigenous labourers), and statement 18 (Internally migrated labourers have led to the formation of rapid urban slums in the city) are with high loadings of $0.816,0.745$ and 0.596 respectively. They are related and have been named as 'adversely affects the urban landscape'. For factor 4, statement 2 (Internally migrated labourers provide stiff competition to the indigenous labourers available) and statement 13 (Internally migrated labourers have created unemployment for indigenous labourers) have high loadings of 0.838 and 0.664 respectively. They are related and have been named as 'threat to indigenous labourers'. For factor 5, statement 9 (Internally migrated labourers may be a source of petty crimes in the city than indigenous labourers) and statement 12 (Internally migrated labourers create more socio economic problems than indigenous labourers) have high loadings of 0.912 and 0.547 respectively. They are related and have been named as 'creates socio economic problem'.

For factor 6, statement 3 (Internally migrated labourers are more innovative in comparison to indigenous labourers), statement 6 (Internally migrated labourers are more industrious than indigenous labourers available) and statement 12 (Internally migrated labourers can do more work with limited resources than indigenous labourers) have high loadings of $0.739,0.556$ and 0.543 respectively. They are related and have been named as 'are innovative'. For factor 7, statement 1 (Internally migrated labourers are readily available in comparison to indigenous labourers) and statement 4 (Internally migrated labourers have easy accessibility in comparison to indigenous labourers) have high loadings of 0.455 and 0.541 respectively. They are related and have been named as 'easy availability'. Further for the same factor, statement 7 (Internally migrated labourers can perform multiple task compared to indigenous labourers) and statement 24 (Internally migrated labourers are highly skilled compared to indigenous labourers) have high loadings of 0.779 and 0.473 respectively. They are related and have been named as 'perform labourious tasks'. For factor 8, statement 11 (Internally migrated labourers hardly contribute anything to government revenue earnings) and statement 25 (Internally migrated labourers have a lesser level of civic sense than indigenous labourers) have high loadings of 0.559 and 0.836 respectively. They are related and have been named as 'non contributor to Government revenue'. For factor 9, statement 17 (Internally migrated labourers are more effective than indigenous labourers) have a high loading of 0.914. It has been named as 'effective labourers'. The appropriate names as derived are listed in Table 4.

For each factor, name was given with the exception for factor 7 (comprising of 4 statements with high loadings which denoted two different meanings for the related statements). So a total of 10 names were derived. Based on the 10 names as per Table 4, 10 final attitudinal statements were developed. 
Issues and Challenges of Employing Internally Migrated Labourers

Table 4: Derivation and Naming of the Key Factors

\begin{tabular}{lll}
\hline Factor & Variables / Statements & Names \\
\hline F1 & V14, V15, V16 & Provider of cheap labour \\
F2 & V10, V19, V20, V21, V23 & Easy to manage and flexible \\
F3 & V5, V8, V18 & Adversely affects urban landscape \\
F4 & V2, V13 & Threat to indigenous labourers \\
F5 & V9, V12 & Creates socio economic problem \\
F6 & V3, V6, V12 & Innovativeness \\
F7 & V1, V4 & Easy availability \\
F7 & V7, V24 & Performs labourious tasks \\
F8 & V11, V25 & Non contributor to Government revenue \\
F9 & V17 & Effective labourers \\
\hline
\end{tabular}

Details of variables as per Table-1

The detailed statements were included in Table 5. To know the overall perception of respondents towards using internally migrated labourers, an $11^{\text {th }}$ statement has been framed as 'labourers are indispensable for the city's overall infrastructural growth and development'.

Table 5: Attitudinal Statements

S1 Internally migrated labourers are easily availability when compared to indigenous labourers

S2 Internally migrated labourers can perform more labourious tasks compared to indigenous labourers

S3 Internally migrated labourers are more innovative compared to indigenous labourers

S4 Internally migrated labourers are more effective in comparison to indigenous labourers

S5 Internally migrated labourers can be easily managed and flexible compared to indigenous labourers

S6 Internally migrated labourers provide services at cheap wages compared to indigenous labourers

S7 Internally migrated labourers do not contribute in any way to the Government revenue

S8 Internally migrated labourers can adversely affects the urban landscape compared to indigenous labourers

S9 Internally migrated labourers are a threat to indigenous labourers as they provide competition

S10 Internally migrated labourers create more socio economic problem compared to indigenous labourers

S11 Labourers are indispensable for the city's overall infrastructural growth and development

'S' stands for Statements

For the attitudinal statements framed as per Table 5, the same attitudinal scale as used in the first phase was adopted in the second phase. As a final phase of field study, a final sample of 223 respondents was taken for survey. Among the sampling units, 61 belonged to the Public Sector / Government sector, 70 belonged to the Private Sector, 42 were Self Employed, 38 were Professionals, 7 belonged to the Unemployed / Housewife / Student category and 5 were Senior Citizen of the city. 
Dipankar Malakar and Shazeed Ahmed

Regression analysis (as per Table 6) was used on the collected data to find out the most significant issues as felt by the citizens. In conducting Regression Analysis, statements no 01 to statement no 10 were used as the independent variables. Further statement no 11 was used as the dependent variable.

Table 6: Regression Table

\begin{tabular}{|c|c|c|c|c|}
\hline Slno & $\begin{array}{l}R=0.509 \\
\text { Statements }\end{array}$ & $\begin{array}{c}R^{2}=0.259 \\
\text { Standardised } \\
\text { Co-efficient } \\
\text { (Beta) }\end{array}$ & $\begin{array}{c}F=07.421 \\
t\end{array}$ & $\begin{array}{c}\text { Significance } \\
=0.000 \\
D W=1.705\end{array}$ \\
\hline S1 & $\begin{array}{l}\text { Internally migrated labourers are easily availability when } \\
\text { compared to indigenous labourers }\end{array}$ & .240 & 4.838 & .000 \\
\hline S2 & $\begin{array}{l}\text { Internally migrated labourers can perform more labourious } \\
\text { tasks compared to indigenous labourers }\end{array}$ & .094 & 2.262 & .025 \\
\hline S3 & $\begin{array}{l}\text { Internally migrated labourers are more innovative } \\
\text { compared to indigenous labourers }\end{array}$ & -.009 & -.222 & .825 \\
\hline S4 & $\begin{array}{l}\text { Internally migrated labourers are more effective in } \\
\text { comparison to indigenous labourers }\end{array}$ & .098 & 2.056 & .041 \\
\hline S5 & $\begin{array}{l}\text { Internally migrated labourers can be easily managed and } \\
\text { flexible compared to indigenous labourers }\end{array}$ & -.126 & -3.281 & .001 \\
\hline S6 & $\begin{array}{l}\text { Internally migrated labourers provide services at cheap } \\
\text { wages compared to indigenous labourers }\end{array}$ & -.107 & -2.963 & .003 \\
\hline S7 & $\begin{array}{l}\text { Internally migrated labourers do not contribute in any } \\
\text { way to the Government revenue }\end{array}$ & -.008 & -.262 & .794 \\
\hline S8 & $\begin{array}{l}\text { Internally migrated labourers can adversely affect urban } \\
\text { landscape compared to indigenous labourers }\end{array}$ & -.106 & -2.484 & .014 \\
\hline S9 & $\begin{array}{l}\text { Internally migrated labourers are a threat to indigenous } \\
\text { labourers as they provide competition }\end{array}$ & .091 & 2.372 & .019 \\
\hline S10 & $\begin{array}{l}\text { Internally migrated labourers create more socio economic } \\
\text { problem compared to indigenous labourers }\end{array}$ & -.015 & -.399 & .690 \\
\hline
\end{tabular}

Level of significance at 5 percent

From the regression Table 6 it was found that the perception towards the statement S1 (internally migrated labourers are easily availability when compared to indigenous labourers) was significant (with $P$ value $\leq 0.000$, beta $=0.240$ ) which influences attitude by an overall 24.0 percent. Secondly perception towards the statement S2 (internally migrated labourers can perform more labourious tasks compared to indigenous labourers) was significant (with $\mathrm{P}$ value $\leq 0.025$, beta $=0.094$ ) which influences attitude by an overall 09.4 percent. Thirdly the perception towards the statement S4 (internally migrated labourers are more effective in comparison to indigenous labourers) was significant (with $\mathrm{P}$ value $\leq 0.041$, beta $=0.098$ ) which influences attitude by an overall 09.8 percent. Fourthly the perception towards the 
statement S5 (internally migrated labourers can be easily managed and flexible compared to indigenous labourers) was significant (with $P$ value $\leq 0.001$, beta $=0.126$ ) which influences attitude by an overall 12.6 percent.

Fifthly the perception towards the statement S6 (internally migrated labourers provide services at cheap wages compared to indigenous labourers) was significant (with $P$ value $\leq 0.003$, beta $=0.107$ ) which influences attitude by an overall 10.7 percent. Sixthly the perception towards the statement S8 (internally migrated labourers can adversely affects the urban landscape compared to indigenous labourers) was significant (with $\mathrm{P}$ value $\leq 0.014$, beta $=0.106$ ) which influences attitude by an overall 10.6 percent. Lastly the perception towards the statement S9 (internally migrated labourers are a threat to indigenous labourers as they provide competition) was significant (with P value $\leq 0.019$, beta $=0.091$ ) which influences attitude by an overall 09.1 percent.

On the other hand as per Table 6, it was found that the perception of the respondents towards statement S3 (internally migrated labourers are more innovative compared to indigenous labourers) with (P value $\geq 0.825$ ), towards statement S7 (internally migrated labourers do not contribute in any way to the Government revenue) with (P value $\geq 0.794$ ) and towards statement S10 (internally migrated labourers create more socio economic problem compared to indigenous labourers with ( $\mathrm{P}$ value $\geq$ 0.690) are not significant.

\section{Results and Discussion}

\subsection{Citizen Perception Analysis}

Citizens perceive internally migrated labourers to be easily available. Such labourers migrate to the city during the agricultural slack season in substantial numbers from the populated char areas. They are perceived to perform very labourious tasks as they are culturally trained to do hard tasks. It is also perceived that migrated labourers are more effective at work. This is because such labourers have a specific intention to work, earn and return back to native places after work is over. Further it is perceived that migrated labourers can be easily managed and are flexible as their communality is less.

Citizens perceived the migrated labourers to be accessible at cheap rates. This is possible as their cost of living and bargaining power is low. Consequently the average wages in the labour market is decreased by competition. Such labourers adversely affect the urban landscape as significant population of migrant labourers live in densely populated areas. Further it is perceived that migrant labourers are a threat to indigenous labourers as they provide competition. However the reality is that service from the indigenous labourers is not forthcoming in the construction sector.

Citizens view the migrated labourers to be non-innovative. Further there is a perception that such migrated labourers are not contributing to the government revenue. But as such labourers as not taxable, they are not obligated to pay direct tax. However the government earns indirect tax when they purchase various consumable items for personal consumption both at the host region and the region of origin. Lastly it is perceived that migrant labourers sometimes create socio economic problem and they lack much accountability.

Orissa Journal of Commerce, 42(2) (C) 2021 
Dipankar Malakar and Shazeed Ahmed

\subsection{Key Issues and Implications}

Based upon the findings of the field work related to the first objective, key issues have been identified. Suitable measures from the managerial perspective are suggested to address such issues as given in Table 7.

Table 7: Key Issues and Managerial Implications

\begin{tabular}{|c|c|}
\hline Issues & Implications \\
\hline Easy availability of migrant labourers & $\begin{array}{l}\text { Based upon the economic theory of labour mobility as well as demand } \\
\text { and supply in the labour market, migrant labourers may be } \\
\text { conveniently employed for the benefit of the employers. }\end{array}$ \\
\hline Performs labourious tasks & $\begin{array}{l}\text { As the labourers have fewer skills their bargaining power is weak. At } \\
\text { times they may be employed in double shifts with incentives for extra } \\
\text { income. Hence they may be employed optimally. }\end{array}$ \\
\hline Significantly not innovative & $\begin{array}{l}\text { High degree of innovative is not an essential requirement for } \\
\text { labourious jobs. Hence their non-innovativeness may not be an issue } \\
\text { in their employment. }\end{array}$ \\
\hline Effective at work & $\begin{array}{l}\text { As such labourers are effective at work, they may be suitably employed } \\
\text { in projects works with deadlines. Further they can be employed in ad- } \\
\text { hoc works to the benefit of the employer. }\end{array}$ \\
\hline Manageable and flexible & $\begin{array}{l}\text { Flexibility and execution of work as per command is a good quality } \\
\text { of the migrant labourer. Hence such labourers may be employed in } \\
\text { works where services from the indigenous labourers is not } \\
\text { forthcoming }\end{array}$ \\
\hline Accessible at cheap wages & $\begin{array}{l}\text { The concept of yield management can be applied in employing the } \\
\text { labourers to the benefit of the employers. Alternative models may be } \\
\text { worked out so that such labourers may be perennial employed. }\end{array}$ \\
\hline Non contributor to government revenue & $\begin{array}{l}\text { As major part of earnings of workers are remitted to the native places, } \\
\text { the purchasing power of their families' increases. Thus purchase } \\
\text { transactions in the native place leads to increase of indirect tax. }\end{array}$ \\
\hline Adversely affect urban landscape & $\begin{array}{l}\text { Employers can make arrangement for labourers during the peak } \\
\text { seasons in planned designated colonies in the outskirts of the city. } \\
\text { Rules may be given to labourers to maintain the etiquettes of city life. }\end{array}$ \\
\hline A threat to indigenous labourers & $\begin{array}{l}\text { Internally migrated labourers are not a threat as they conform to the } \\
\text { principle of survival of the fittest in the market. They cater to a niche } \\
\text { labour market and hence can be employed profitably. }\end{array}$ \\
\hline Creation of socio economic problems & $\begin{array}{l}\text { The task to infuse civic sense and cultivation of good habits can be } \\
\text { made the responsibility of the employer. Hence labourers can be } \\
\text { educated on the city rules and regulations with the do's and do not's. }\end{array}$ \\
\hline
\end{tabular}




\section{Conclusions}

The topic of internal migration is an important area of discourse. Internal migration of labourers from the rural to the urban areas takes place due to economic reasons. Such migration is desirable as it accrues manifold benefits to the host region and the region of origin. Migration leads to growth and development of the economy at the place of destination. It also emancipates the migrant and their families from an impoverished life. However such phenomenon is accompanied by various issues to the host region as well.

Critics contend that internal migration from rural to urban areas, lead to urban slums and consequently affect the beauty of the urban landscape. Sometimes petty socio economic problems are also created by migrant labourers in the city. Hence hiring migrant labourers without maintaining the etiquettes of a disciplined city landscape may create problems for the city administrators and the city dwellers. Proper rules are required and to be followed during employment of such labourers in the city for the overall benefit of the stakeholders. Further study can be carried out in the area of living condition, wage discrimination, gender issues and economic impact in the native place of migrated labourers.

\section{References}

Borah, J. (2014). The Rural-Urban Migration Pattern in Guwahati's Environment. Working papers of UNIL / University of Lausanne, Switzerland, retrieved May 2, 2020, from https://www.unil.ch/iguurban/en/home/ menuinst/activities/working-papers/abstracts-canterbury-2011/borah.html.

Borhade, A., Dey, S., \& Sharma, J. (2016). Towards a Better Response to Internal Labour Migration in India: Key Recommendations for the 12th Plan. Report submitted to the Indian Institute of Public Health, published by Planning Commission of India, retrieved from http://planningcommission.nic.in/data/ngo/csw/ csw_lobor.pdf.

Debnath, M., Ray, S., Islam, N., \& Sar, N. (2017). Migration patterns and urban growth in north-east India: A study in Siliguri city. Quest-The Journal of UGC-HRDC Nainital, 11(2). doi: 10.5958/2249-0035.2017.00016.x.

Economywatch (2010). Defination of Construction Industry, June 29, 2010, retrieved from www.economywatch.com/world-industries/construction.

Gimba, Z., \& Kumshe, M. (2001).Causes and effects of rural-urban migration in Borno State: A case study of Maiduguri Metropolis. Asian Journal of Business and Management Sciences, 1(1), 168-172.

Handral, A., R., Anbukkani, P., \& Kumar, P. (2018). Internal labour migration in India: Recent trends and patterns. Ann. Agric. Res. New Series, 39(2), 1-8, retrieved from: www.researchgate.net/publication/331865291

India Population Report (2020). Population of Guwahati 2020 (Demographic, Facts, etc) - India Population 2020, retrieved from https://indiapopulation2020.in/population-of-guwahati-2020.html

International Organization for Migration. (2010). World Migration Report 2010: the future of migration: building capacities for change, Geneva, retrieved from https:www.iom.int/world-migration-report-2010.

Jane, C., A. (2016). A Study on the Internal Migrant Labour - Issues and Policies. Indian Journal of Applied Research, 6(4), 81-83, retrieved from https://www.worldwidejournals.com /indian-journal-of-applied-research.

Labour Migration Infosheet (2008). Labour and Facilitated Migration Division, (International Organization for Migration) IOM and Labour Migration, 42_08, 1, retrieved from http://www.iom.int.

Orissa Journal of Commerce, 42(2) (C) 2021 
Dipankar Malakar and Shazeed Ahmed

Lalrampuii, R. (2016). Economic Perspective of Migration in North-East India, DU Journal of Undergraduate Research and Innovation, 2(2), 128-136, retrieved from www. http://Journals.du.ac.in/ugresearch/vol5.

Lexico.com (2020). Defination of Migrant, retrieved from www.lexico.com/defination/migrant.

Mahapatro, S. (2014). Contemporary Patterns and Issues of Internal Migration in India: Evidence from NSSO," paper presented at KNOWMAD conference on Internal Migration and Urbanization, Dhaka, May 1st. retrieved from the https://www.thefreelibrary.com/Internal + migration+in+developing+economies.

Mahapatro, S. R. (2013). Changing pattern of Internal Migration in India, Issues and challenges. Indian Economic Journal, 61(1), 1-18, Sage publication.

Malhotra, N., \& Devi, P. (2017). Analysis of Factors Affecting Internal Migration in India. Amity Journal of Economics, 1(2), 34-51.

Mander, H., \& Sahgal, G. (2010). Internal Migration in India: Distress and Opportunities. A study sponsored and supported by Dan Church India over the year 2010, 1-22.

Nunnally, J. C. (1978). Psychometric Theory (2nd ed.). New York: McGraw-Hill.

Sanyal, T., \& Maity, K. (2018). On Labour Migration in India: Trends, Causes and Impacts. Economic Affairs, 63(1), 57-69, March 2018, DOI: 10.30954/0424-2513.2018.00150.8.

Srivastava, R. (1968). Migration and the Labour Market in India. The Indian Journal of Labour Economics, 41(4), 583616.

Sudman (1976). Applied Sampling, San Diego, CA: Academic Press.

Todaro, M. P. (1969). A Model of Labor Migration and Urban Unemployment in Less Developed Countries, The American Economic Review, 59(1), 138-148.

World Urbanization Prospect Report (2019). United Nations Department of Economic and Social Affairs, Population Division, World Urbanization Prospects-2018 Revision, retrieved from https://population.un.org/ wup/ Publications /Files/WUP2018-Report.pdf.

Weiner, M. (2002). The global migration crisis: challenge to states and to human rights. New York: Harper Collins College Publishers. 